Doi: https://doi.org/10.24036/jep/vol2-iss2/212

\title{
Pengembangan Instrumen Penilaian Kemampuan Berpikir Tingkat Tinggi Materi Sistem Pendengaran dan Sonar SMP
}

\author{
Vita Ria Mustikasari ${ }^{1)}$, Munzil ${ }^{2)}$, Lia Puji Lestari ${ }^{3)}$ \\ ${ }^{1,2}$ Dosen Prodi Pendidikan IPA, FMIPA, Universitas Negeri Malang \\ ${ }^{3)}$ Mahasiswa Prodi Pendidikan IPA, FMIPA, Universitas Negeri Malang \\ vita.ria.fmipa@um.ac.id
}

\begin{abstract}
The aim of this study is to produce a higher-order thinking skills assessment instrument on the material of the hearing and sonar system for Junior high school students that are valid and reliable. Indicators of higher-order thinking skills (IKBTT) are developed based on the cognitive dimension of Bloom's Taxonomy which includes the skills to analyze (C4), evaluate (C5) and create (C6). The assessment instrument developed was a multiple choice test with open reasons. Multiple choice test with open reason is a multiple choice question with four answer choices completed with the reason for choosing an answer. The instrument is equipped with an assessment rubric in the form of a holistic rubric to assess the relationship between multiple choice answers and reasons for choosing answers. The results of the validation of material aspects, construction, and language show that the products developed are very feasible with an average score of $85.7 \%$. The instrument was empirically tested with the number of subjects trying as many as 59 students of 8th grade Junior high school. Based on the results of empirical trials of multiple choice questions with open reasons obtained 25 valid questions with multiple choice reliability of 0.745, and reason reliability of 0.929. The number of questions produced based on C4 cognitive dimensions were 12 questions (48\%), C5 cognitive dimensions were 9 questions (36\%), and C6 cognitive dimensions were 4 questions (16\%). This study produced an instrument for assessing higher-order thinking skills in the material of the hearing and sonar system for Junior high school students that were valid and reliable.
\end{abstract}

Keywords : Assessment instruments, Higher-order thinking skills, Hearing and sonar system

This is an open access article distributed under the Creative Commons 4.0 Attribution License, which permits unrestricted use, distribution, and reproduction in any medium, provided the original work is properly cited. @2018 by author and Universitas Negeri Padang.

\section{PENDAHULUAN}

Kemampuan berpikir tingkat tinggi didefinisikan sebagai penggunaan pikiran secara lebih luas untuk menemukan tantangan baru (Rofiah dkk, 2013). Kemampuan berpikir tingkat tinggi dapat dikembangkan melalui kegiatan memecahkan masalah dalam pembelajaran. Masalah yang diangkat berupa situasi-situasi baru yang dipecahkan dengan pengetahuan dan pengalaman yang sudah dimiliki oleh siswa. Kegiatan memecahkan masalah tersebut melibatkan kemampuan untuk menganalisis, mengevaluasi, dan mengkreasi (Sofi yah dkk, 2015).

Hasil Trend in International Mathema tics and Science Study (TIMSS) tahun 2011 tentang kemampuan berpikir kategori 8th Grade Science, Indonesia berada pada urutan ke 40 dari 42 negara. Persentase kemam puan berpikir di atas rata-rata (advance) sebesar 0\%, tingkat tinggi (high) sebesar 3\%, tingkat sedang (intermediet) sebesar 19\%, dan tingkat rendah (low) sebesar 54\%. Hasil Programme for Inter national Student Assessment (PISA) tentang prestasi literasi sains Tahun 2015, Indonesia mengalami peningkatan nilai dari 382 pada tahun 2012 menjadi 403 pada tahun 2015 . Namun, nilai tersebut masih berada di bawah nilai rata-rata negara OECD (493) dan negara di Asia Tenggara seperti Singapura (556) dan Thailand (421). Berdasarkan data tersebut, ke mampuan berpikir siswa Indonesia masih rendah sehingga perlu dikembangkan.

Kemampuan berpikir siswa dapat dikem bangkan melalui program pembelajaran ter utama yang berhubungan dengan proses kognitif penalaran melalui suatu pengkondisian untuk berpikir melalui proses latihan menjawab soal yang berorientasi pada kemampuan berpikir tingkat tinggi (Yildirim \& Ozkah raman, 2011; Litbang Kemendikbud, 2013). Selain itu, model 
penilaian yang digunakan dalam program pem belajaran berpengaruh terhadap kemampuan berpikir siswa (Istiyono dkk, 2014). Alternatif penilaian dibutuhkan untuk menilai kemampuan berpikir siswa (Gloria, 2012).

Berdasarkan hasil wawancara dengan guru IPA SMP di Kota Batu dan Kabupaten Malang, model penilaian yang sering digunakan berupa soal pilihan ganda. Soal pilihan ganda yang sering dikembangkan masih terbatas pada dimensi kognitif $\mathrm{C} 1, \mathrm{C} 2$ dan $\mathrm{C} 3$. Jenis soal dengan dimensi kognitif yang rendah tidak melatih kemampuan berpikir siswa (Puspitasari dan Purnamasari, 2012). Soal dengan dimensi kognitif yang rendah cenderung menguji aspek ingatan dan pemahaman konsep. Selain itu, kele mahan tes pilihan ganda memberi kesempatan siswa untuk menebak jawaban benar (Sa'adah dkk, 2014). Berdasarkan hal tersebut, instrumen penilaian berupa tes pilihan ganda yang selama ini dikembangkan masih terbatas pada dimensi kognitif yang rendah dan memberi kesempatan siswa untuk menebak jawaban benar.

Tes pilihan ganda dapat mengukur be berapa kemampuan berpikir tingkat rendah dan tingkat tinggi (Killoran dalam King, 2010). Tes pilihan ganda dapat digunakan untuk menilai kemampuan berpikir kritis mikrodimensi (King dkk, 2010). Kemampuan berpikir kritis mikrodimensi seperti mengidentifikasi asumsi yang paling masuk akal, mengakui tujuan penulis, memilih kesimpulan yang paling dipertahankan, dan lain sebagainya. Tes pilihan ganda yang dikembangkan untuk mengukur kemampuan berpikir tingkat tinggi dapat berupa soal yang bersifat (1) mengenali terminologi penting, (2) menunjukkan perbandingan dan kontras, (3) menunjukkan sebab dan akibat, (4) menggeneralisasikan, dan (5) berisi tentang kronologi, fakta, dan opini dari sumber yang diberikan (Killoran dalam King, 2010).

Instrumen penilaian yang berorientasi pada kemampuan berpikir tingkat tinggi penting dikembangkan untuk menghadapi kemajuan ilmu pengetahuan dan teknologi karena dapat melatih siswa dalam memecahkan masalah dalam kehidupan sehari-hari (Lisa dkk, 2012). Instrumen penilaian berpikir tingkat tinggi dapat dikembangkan melalui tes pilihan ganda dengan alasan terbuka. Tes pilihan ganda dengan alasan terbuka merupakan soal pilihan ganda dengan empat pilihan jawaban dilengkapi dengan alasan pemilihan jawaban. Alasan pemilihan jawaban siswa, dapat digunakan guru untuk mengukur tingkat berpikir siswa terhadap penguasaan materi pembelajaran lebih mendalam (Inteni dkk, 2013). Penggunaan alasan untuk menjawab butir soal pilihan ganda menjadi cara yang efektif untuk menilai pembelajaran yang bermakna (Shidiq dkk, 2014). Salah satu materi yang dapat digunakan untuk mengembangkan kemampuan berpikir tingkat tinggi adalah materi sistem pendengaran dan sistem sonar. Materi sistem pendengaran dan sistem sonar erat de ngan kehidupan sehari-hari. Pada materi tersebut siswa dapat dihadapkan dengan berbagai masalah kontekstual yang menuntut kemampuan berpikir dan memecahkan masalah (Silver, 2004). Pembelajaran berbasis masalah dapat mengembangkan kemampuan berpikir tingkat tinggi siswa (Weiss, 2003). Siswa dilatih dalam memecahkan permasalahan yang membutuhkan pemikiran untuk menganalisis, menilai, dan mengkreasi untuk mencapai kemampuan berpikir tingkat tinggi (Sofiyah dkk, 2015). Masalah yang diangkat berupa situasi-situasi baru yang dapat dipecahkan dengan pengetahu an dan pengalaman yang dimiliki siswa. Ber dasarkan hal tersebut, materi sistem pen dengaran dan sistem sonar dapat dikembangkan menjadi soal untuk membangun kemampuan berpikir tingkat tinggi.

Pengembangan instrumen penilaian ber pikir tingkat tinggi yang dilakukan oleh Rofi'ah dkk (2013) pada materi sifat cahaya dan alat optik SMP telah memenuhi syarat sebagai instrumen tes yang baik untuk menguji kemam puan berpikir tingkat tinggi siswa dengan reliabilitas 0,87 untuk paket $\mathrm{A}$ dan 0,557 untuk paket $\mathrm{B}$. Hasil pengembangan instrumen peni laian Two Tier Multiple-Choice yang dikem bangkan oleh Shidiq dkk (2014) pada materi kelarutan dan hasil kali kelarutan mampu mengukur keterampilan berpikir tingkat tinggi dengan angka konsistensi 41,6\%. Instrumen penilaian kemampuan berpikir tingkat tinggi yang dikembangkan oleh Lisa dkk (2012) pada materi sistem respirasi dan ekskresi dinyatakan valid, reliabel dan praktis serta berpengaruh positif terhadap hasil belajar kognitif. Berda sarkan penelitian yang telah dilakukan, instru men penilaian untuk melatih kemampuan berpi kir tingkat tinggi siswa pada materi sistem pen dengaran dan sistem sonar belum dikembang kan. 
Berdasarkan uraian tersebut, maka dilakukan penelitian dan pengembangan untuk menghasilkan instrumen penilaian kemampuan berpikir tingkat tinggi tentang sistem pen dengaran dan sistem sonar untuk kelas VIII SMP yang valid dan reliabel.

\section{METODE PENELITIAN}

Penelitian ini merupakan jenis pene litian dan pengembangan (Research and Develop ment) yang bertujuan untuk mengha silkan produk berupa instrumen penilaian kemampuan berpikir tingkat tinggi. Model yang digunakan dalam penelitian dan pengembangan ini mengacu pada Borg \& Gall (1983) yang diadaptasi sesuai dengan kebutuhan penelitian.

Tahap penelitian ini dibagi menjadi dua, yaitu tahap studi pendahuluan dan tahap pengembangan. Studi pendahuluan dilakukan untuk mendapat informasi berupa, jenis instrumen penilaian yang digunakan di sekolah, menganalisis kebutuhan pengem bangan instrumen, mengembangkan instrumen penilaian kemampuan berpikir tingkat tinggi dan me ngembangkan rubrik peni laian. Tahap pengem bangan instrumen di mulai dari validasi oleh ahli instrumen penilaian. Validasi oleh ahli instrumen penilaian bertujuan untuk menilai kelayakan instrumen dan kebenaran konsep. Validasi kelayakan bertujuan untuk menilai aspek materi, konstruksi dan bahasa. Validasi kebe naran konsep untuk mengetahui kebenaran konsep yang digunakan dalam instrumen penilaian.

Kelayakan aspek yang dinilai ditun jukkan pada Tabel 1.

Tabel 1. Aspek Validasi Kelayakan

\begin{tabular}{|l|}
\hline \multicolumn{1}{|c|}{ Aspek yang dinilai } \\
\hline Materi \\
- Perumusan indikator kemampuan berpikir \\
tingkat tinggi sesuai dengan Kompetensi \\
Dasar \\
- Indikator butir soal mengacu pada \\
indikator kemampuan berpikir ting kat \\
tinggi \\
- Butir soal mampu mengukur ke mampuan \\
berpikir tingkat tinggi sesuai dengan \\
indikator butir soal \\
- Butir soal mampu mengukur ke mampuan \\
berpikir tingkat tinggi sesuai dengan \\
dimensi kognitif \\
- Permasalahan yang diangkat da lam soal \\
terkait dengan penerapan kehidupan \\
sehari-hari \\
\hline
\end{tabular}

Kostruksi

- Butir soal dirumuskan secara jelas

- Pilihan jawaban homogen dan logis

- Grafik, tabel, gambar, peta, atau yang sejenisnya jelas dan terbaca

Bahasa

- Rumusan soal menggunakan bahasa yang komunikatif

- Rumusan soal menggunakan bahasa yang sesuai dengan kaidah Baha sa Indonesia

- Rumusan butir soal tidak menggunakan kata/kalimat yang menimbul kan penafsiran ganda

Data hasil validasi oleh ahli instrumen penilaian yang diperoleh berupa data kuanti tatif dan kualitatif. Data kuantitatif yang diperoleh menggunakan skala Guttman Ya dan Tidak, Ya berarti skor 1 dan tidak berarti skor 0 untuk mengetahui kelayakan aspek materi, konstruksi, dan bahasa. Data tersebut kemudian dianalisis melalui perhitungan persentase skor pada setiap jawaban dari setiap pertanyaan dalam lembar validasi.

Analisis persentase hasil validasi oleh ahli instrumen penilaian dirumuskan sebagai berikut.

$$
\mathrm{P}=\frac{\Sigma x}{n} x 100 \%
$$

Keterangan:

$\mathrm{P}=$ Skor persentase

$\Sigma \mathrm{x}=$ Jumlah jawaban dari tiap responden tiap item pertanyaan

$\mathrm{n}$ = Nilai jawaban jika seluruh responden menjawab sangat layak

Penilaian hasil validasi selanjutnya di bandingkan dengan kriteria pada Tabel 2 .

Tabel 2. Kriteria Kelayakan

\begin{tabular}{|c|c|}
\hline Persentase (\%) & Kriteria \\
\hline $81-100$ & Sangat layak \\
\hline $61-80$ & Layak \\
\hline $41-60$ & Cukup layak \\
\hline $21-40$ & Kurang layak \\
\hline $0-20$ & Tidak Layak \\
\hline
\end{tabular}

(Riduwan, 2006:89)

Selanjutnya dilakukan uji coba empiris untuk menguji validitas dan reliabilitas. Subjek uji coba dalam penelitian dan pengembangan ini terdiri dari 59 siswa SMP kelas VIII yang telah mempelajari materi sistem pendengaran dan 
sistem sonar di salah satu SMP Negeri di Kabupaten Malang.

Hasil validasi digunakan sebagai dasar melakukan revisi dan penyempurnaan instrumen penilaian kemampuan berpikir tingkat tinggi. Setelah dilakukan revisi instrumen penilaian kemudian dilanjutkan dengan uji coba empiris. Uji coba empiris bertujuan untuk mengetahui validitas dan reliabilitas soal yang dikembang kan. Uji validitas dan reliabilitas di lakukan terhadap butir soal pilihan ganda dan alasan.

Validitas butir soal pilihan ganda $\left(\mathrm{r}_{\text {bis }}\right)$ diperoleh dari skor butir soal yang dinyatakan dengan 1 (satu) untuk butir soal yang dijawab benar, dan 0 (nol) untuk butir soal yang dijawab salah. Validitas alasan $\left(\mathrm{r}_{\mathrm{it}}\right)$ diperoleh dari skor butir soal yang dinyatakan dengan $0,0.5,1,2,3$, 4, dan 5 berdasarkan rubrik penilaian yang telah dikembangkan. Validitas tes pilihan ganda dan alasan dapat diketahui dengan menggunakan bantuan program komputer.

Setelah diperoleh harga $r_{\text {bis }}$ dan $r_{i t}$, berikutnya dibandingkan dengan harga korelasi poin biseral $\left(\mathrm{r}_{\text {tab }}\right)$ dengan taraf signi fikansi $5 \%$. Jika $r_{\text {bis }}$ dan $r_{i t}$ lebih besar dari $r_{\text {tab }}(0,05)$ maka butir tersebut valid sedangkan $r_{\text {bis }}$ dan $r_{i t}$ kurang dari $r_{\text {tab }}(0,05)$ maka butir soal tersebut tidak valid.

Reliabilitas tes pilihan ganda dan alasan dapat diketahui dengan menggunakan bantuan program komputer. Makna angka korelasi tes $\left(\mathrm{r}_{\mathrm{II}}\right)$ secara keseluruhan dapat dilihat pada Tabel 3.

Tabel 3. Makna Angka Korelasi Tes

\begin{tabular}{|l|l|}
\hline \multicolumn{1}{|c|}{ Angka Korelasi } & \multicolumn{1}{c|}{ Makna } \\
\hline $0,800<\mathrm{r}_{\text {II }} \leq 1,00$ & Sangat tinggi \\
\hline $0,600<\mathrm{r}_{\text {II }} \leq 0,800$ & Tinggi \\
\hline $0,400<\mathrm{r}_{\text {II }} \leq 0,600$ & Sedang \\
\hline $0,200<\mathrm{r}_{\text {II }} \leq 0,400$ & Rendah \\
\hline $0,000<\mathrm{r}_{\text {II }} \leq 0,200$ & Sangat rendah \\
\hline
\end{tabular}

(Adaptasi Sofiyah, 2015)

Rubrik penilaian tes pilihan ganda alasan dengan terbuka yang dikembangkan dapat dilihat pada Tabel 4.

Tabel 4. Rubrik Penilaian Tes Pilihan Ganda Alasan Terbuka

\begin{tabular}{|c|l|c|}
\hline $\begin{array}{c}\text { Jawaban } \\
\text { Objektif }\end{array}$ & \multicolumn{1}{|c|}{ Deskriptor } & Skor \\
\hline Benar & $\begin{array}{l}\text { Level 4 (Superior } \\
\text { Achievement) } \\
\text { - Menunjukkan kemampuan } \\
\text { yang lebih dalam } \\
\text { menganalisis informasi }\end{array}$ & 5 \\
\hline
\end{tabular}

\begin{tabular}{|c|c|c|}
\hline & $\begin{array}{l}\text { - Memberikan variasi fakta- } \\
\text { fakta untuk menggali } \\
\text { konsep yang terlibat } \\
\text { - Secara ekstensif } \\
\text { menggunakan pengetahuan } \\
\text { yang telah dimiliki untuk } \\
\text { memberikan pemahaman } \\
\text { mendalam tentang suatu } \\
\text { masalah } \\
\text { - Mengaitkan situasi lama } \\
\text { dengan kemungkinan } \\
\text { situasi yang yang akan } \\
\text { terjadi } \\
\text { - Menggunakan strategi- } \\
\text { strategi yang sesuai } \\
\text { - Perhitungan benar }\end{array}$ & \\
\hline Benar & $\begin{array}{l}\text { Level } 3 \text { (Commendable } \\
\text { Achievement) } \\
\text { - Menunjukkan kemampuan } \\
\text { dalam menganalisis } \\
\text { informasi } \\
\text { - Memberikan fakta-fakta } \\
\text { untuk menggali konsep } \\
\text { yang terlibat } \\
\text { - Menggunakan pengetahuan } \\
\text { secara umum untuk } \\
\text { memeriksa isu yang } \\
\text { terlibat } \\
\text { - Menggunakan strategi- } \\
\text { strategi yang sesuai } \\
\text { - Perhitungan benar }\end{array}$ & 4 \\
\hline Benar & $\begin{array}{l}\text { Level } 2 \text { (Rudimentary } \\
\text { Achievement) } \\
\text { - Hanya menunjukkan fakta } \\
\text { dan konsep dasar } \\
\text { - Menggunakan strategi } \\
\text { yang sesuai } \\
\text { - Perhitungan sebagian benar }\end{array}$ & 3 \\
\hline Salah & $\begin{array}{l}\text { Level } 2 \text { (Rudimentary } \\
\text { Achievement) } \\
\text { - Hanya menunjukkan fakta } \\
\text { dan konsep dasar } \\
\text { - Menggunakan strategi } \\
\text { yang sesuai } \\
\text { - Perhitungan sebagian benar }\end{array}$ & 2 \\
\hline Benar & $\begin{array}{l}\text { Level } 1 \text { (Minimal } \\
\text { Achievement) } \\
\text { - Menunjukkan fakta tidak } \\
\text { lengkap } \\
\text { - Tidak menggunakan } \\
\text { strategi yang sesuai } \\
\text { - Perhitungan tidak benar }\end{array}$ & 1 \\
\hline
\end{tabular}




\begin{tabular}{|l|l|c|}
\hline Salah & Level 1 (Minimal & 0,5 \\
& Achievement) & \\
& - Menunjukkan fakta tidak & \\
& lengkap & \\
& - Tidak menggunakan & \\
& strategi yang sesuai & \\
& - Perhitungan tidak benar & \\
\hline
\end{tabular}

Produk hasil penelitian dan pengem bangan ini berupa instrumen penilaian untuk mengukur kemampuan berpikir tingkat tinggi yang terdiri dari 25 soal pilihan ganda alasan terbuka. Instrumen penilaian tersebut digunakan untuk mengukur 12 indikator kemampuan berpikir tingkat tinggi KD 3.11 dan 4.11. Indikator kemampuan berpikir tingkat tinggi (IKBTT) yang dikembangkan berdasarkan dimensi kognitif Taksonomi Bloom yang meliputi kemampuan mengana lisis (C4), menge valuasi (C5) dan mengkreasi (C6). Distribusi IKBTT dan soal yang dikembangkan berdasar kan dimensi kognitif Taksonomi Bloom di sajikan pada Tabel 5.

Tabel 5. Distribusi IKBTT dan Soal berdasarkan Dimensi Kognitif Taksonomi Bloom

\begin{tabular}{|c|l|c|c|c|}
\hline No & $\begin{array}{l}\text { Dimensi } \\
\text { Kognitif }\end{array}$ & $\begin{array}{c}\text { Jum } \\
\text { lah } \\
\text { IKBTT }\end{array}$ & $\begin{array}{c}\text { Jum } \\
\text { lah } \\
\text { Soal }\end{array}$ & $\begin{array}{c}\text { Persenta } \\
\text { se Soal }\end{array}$ \\
\hline 1 & C4 & 5 & 12 & $48 \%$ \\
\hline 2 & C5 & 4 & 9 & $36 \%$ \\
\hline 3 & C6 & 3 & 4 & $16 \%$ \\
\hline & Jumlah & 12 & 25 & $100 \%$ \\
\hline
\end{tabular}

Instrumen penilaian kemampuan meng analisis (C4) yang dihasilkan dalam penelitian dan pengembangan ini, siswa dilatih untuk melibatkan kemampuan untuk memecah-mecah bagian atau menghubungkan beberapa konsep yang terlibat dalam mengerjakan soal. Pada instrumen penilaian kemampuan mengevaluasi (C5), siswa dilatih untuk memeriksa, melakukan prediksi terhadap suatu hipotesis, dan menilai metode yang terbaik dalam menyelesaikan soal berdasarkan pengetahuan dan pengalaman yang dimiliki. Pada instrumen penilaian kemampuan mengkreasi (C6), siswa dapat mensintesis informasi atau materi untuk merancang produk baru, membuat gagasan dan merumuskan pe mecahan masalah.

Berdasarkan hasil validasi oleh ahli instrumen penilaian, nilai rata-rata hasil validasi aspek materi, kontruksi dan bahasa pada instrumen penilaian yang dikembangkan adalah

\begin{tabular}{|c|l|c|}
\hline Benar & - Tanpa alasan & 0,5 \\
\hline Salah & - Tanpa alasan & 0 \\
\hline
\end{tabular}

(Modifikasi dari Herman dkk, 1992 dan Iryanti, 2004)

\section{HASIL DAN PEMBAHASAN}

$85,7 \%$ sehingga instrumen peni laian kemampu an berpikir tingkat tinggi yang dikembangkan memenuhi kriteria sangat layak.

Hasil uji empiris soal pilihan ganda dan alasan diperoleh 25 soal yang valid dengan reliabilitas soal pilihan ganda sebesar 0,745 , dan reliabilitas alasan sebesar 0,929. Suatu tes atau instrumen pengukuran dikatakan baik apabila memiliki validitas dan reliabilitas yang tinggi (Djaali dan Muljono, 2008). Dari hasil tersebut menunjukkan bahwa dalam penelitian dan pengembangan ini dihasilkan instrumen penilai an kemampuan berpikir tingkat tinggi tentang sistem pendengaran dan sistem sonar yang valid dan reliabel.

Instrumen penilaian yang dikembang kan dalam penelitian dan pengembangan ini terkait dengan materi sistem pendengaran dan sistem sonar. Siswa dihadapkan dengan berbagai masalah kontekstual yang menuntut kemampuan berpikir dan memecahkan masalah. Siswa dilatih dalam memecahkan permasalahan yang membutuhkan pemikiran untuk menganalisis, menilai, dan mengkreasi untuk mencapai kemampuan berpikir tingkat tinggi (Sofiyah dkk, 2015). Masalah yang diangkat berupa situasisituasi baru yang dapat dipecahkan dengan pengetahuan dan pengalaman yang dimiliki siswa. Berdasarkan hal tersebut, instrumen penilaian tentang sistem pendengaran dan sistem sonar yang dikembangkan dapat melatih kemampuan berpikir tingkat tinggi siswa.

Hasil penelitian Richmond (2007) me nyatakan bahwa kemampuan berpikir yang baik dapat menjadi modal kuat bagi sis wa di Asia untuk dapat menghadapi permasalahan kompleks yang ada pada perkembangan jaman yang modern. Tuntutan perkembangan jaman tidak dengan mudah dapat dihadapi tanpa melalui proses latihan. Yildirim \& Ozkahra man (2011) menegaskan bahwa kemampuan berpikir dapat dikembangkan melalui suatu pengkondisi an untuk berpikir melalui proses latihan menjawab soal yang berorientasi pada kemampu an berpikir 
tingkat tinggi sehingga siswa mampu mengikuti perkembangan ilmu pengetahuan dan teknologi. Berdasarkan hasil penelitian yang telah dilakukan oleh Istiyono dkk (2014); Rofiah dkk (2013); Lisa dkk (2012), instrumen penilaian dapat digu nakan untuk mengembang kan kemampuan berpikir tingkat tinggi siswa.

\section{Kajian}

\section{KESIMPULAN}

Hasil validasi oleh ahli instrumen penilaian, nilai rata-rata hasil validasi aspek materi, kontruksi dan bahasa pada instrumen penilaian yang dikembangkan adalah 85,7 \% sehingga instrumen penilaian kemampuan berpikir tingkat tinggi yang dikembangkan memenuhi kriteria sangat layak. Hasil uji empiris soal pilihan ganda dan alasan diperoleh 25 soal yang valid dengan reliabilitas soal pilihan ganda sebesar 0,745 , dan reliabilitas alasan sebesar 0,929. Dari hasil tersebut menunjukkan bahwa dalam penelitian dan pengembangan ini dihasilkan instrumen penilai an kemampuan berpikir tingkat tinggi tentang sistem pendengaran dan sistem sonar yang valid dan reliabel.

Penggunaan instrumen tes pilihan ganda alasan terbuka dapat memfasilitasi respon dan alternatif kemampuan siswa. Tes pilihan ganda alasan terbuka terbuka dileng kapi dengan empat pilihan jawaban disertai dengan alasan pemilih an jawaban. Berdasarkan ide-ide yang dituliskan oleh siswa, guru dapat mengukur tingkat pemahaman siswa terhadap penguasaan materi pembelajaran lebih mendalam.

\section{Saran}

Beberapa saran yang berkaitan dengan pengembangan instrumen penilaian kemampu an berpikir tingkat tinggi adalah sebagai berikut.

1. Saran untuk Keperluan Pemanfaatan Produk

a. Guru dapat menggunakan instrumen peni laian yang telah dikembangkan pada mate ri sistem pendengaran dan sistem sonar sebagai alternatif penilaian untuk melatih kemampuan berpikir ting kat tinggi siswa.

b. Guru dalam proses mengoreksi pilihan ja waban obyektif dan alasan pemilihan siswa membutuhkan waktu yang lama karena membutuhkan ketelitian dalam menganalisis kemampuan berpikir sis wa.
2. Saran untuk Keperluan Penelitian dan

Pengembangan Lebih Lanjut

Penelitian lebih lanjut dapat dilakukan untuk mengetahui pengaruh penggunaan instrumen penilaian yang telah dikembangkan melalui penelitian eksperimen terhadap ke mampuan berpikir tingkat tinggi siswa.

\section{DAFTAR PUSTAKA}

Djaali \& Muljono, P. 2008. Pengukuran dalam Bidang Pendidikan. Jakarta : Grasindo

Gloria, R.Y. 2012. Pentingnya Asesmen Alternatif Dalam Meningkatkan Kemampuan Berpikir Dan Membaca Ilmiah Siswa Pada Pembelajaran Biologi. Jurnal Scientiae Educatia Volume 1 Edisil.(online),(https://www. syekhnurjati.ac.id /jurnal/ index. php/ sceducatia/ article/view/ 502/440) diakses 20 Februari 2017

Herman, J.A., Aschbacher, P.R., \& Winters, L. 1992. A Practical Guide to AlternativeAssessment.(online),(http:

//files.eric.ed. gov /fulltext/ ED352389 .pdf) diakses 21 Januari 2017

Inteni, Candiasa, \& Suarni. 2013. Pengembangan Instrumen Tes Objektif Pilihan Ganda Yang Diperluas Berbasis Web Untuk Mata Pelajaran Tik Kelas Xi Sman Di Kabupaten Karangasem. E-Journal Program Pasca Sarjana Uni-versitas Pendidikan Ganesha. (online), (http://journals.sagepub.com /doi/pdf/10.3102/0013189X020008015) diakses 21 Januari 2017

Istiyono, Mardaphi, \& Suparno. 2014. Pengembangan Tes Kemampuan Berpikir Tingkat Tinggi Fisika (Pysthots) Peserta Didik SMA. Jurnal Penelitian dan Evaluasi Pendidikan Tahun 18, Nomor 1, 2014. (online), (http://journal.uny. ac.id/index.php/jpep/article/view/2120) diakses 8 September 2016

King,FJ. M.S, Ludwika G., \& Rohani. 2010. Higher Order Thinking Skills. (Online),(http://www.cala.fsu.edu/files/hi gher_order_thinking_skills.pdf) diakses 8 September 2016

Litbang Kemendikbud. 2013. Profil Kemampuan IPA Peserta Didik Indonesia. (online)(http://litbang. kemdikbud.go.id/data/puspendik/HASIL \%20RISET/TIMSS/LAPORAN\%20TIM 
SS\%202011\%20\%20Profil\%20Kemampa n\%20IPA\%20Peserta\%20Didik\%20Indon esia\%20(SMP\%20Kelas\%208)\%20menur ut\%20Benchmark\%20Internasional.pdf) diakses 22 Oktober 2016

Lisa, Prasetyo, A.P.B \& Indiyanti, D.R. 2012. Pengembangan Instrumen Peni laian Ketrampilan Berpikir Tingkat Tinggi Materi Sistem Respirasi dan Ekskresi. Lembaran Ilmu Kependidikan Volume 41 (1) (2012). (online) (http://journal. unnes.ac.id/ artikel_nju/ LIK/ 2226) diakses 29 Oktober 2016

PISA. 2015. PISA 2015 Results in Focus What 15-year-olds know and what they can do with what they know. (online), (https://www.oecd.org/pisa/keyfidings/pis a-2012-results overview.pdf) diakses pada 21 Oktober 2016

Riduwan. 2006. Belajar Mudah Penelitian untuk Guru dan Pemula. Bandung: CV Alfabeta.

Rofiah, Aminah, \& Ekawati. 2013. Penyu-sunan Instrumen Tes Kemampuan Berpikir Tingkat Tinggi Fisika Pada Siswa SMP. Jurnal Pendidikan Fisika (2013) Vol.1

No.2 halaman 17. (online),

(http://www.jurnal.fkip.uns.ac.id/index.ph p/pfisika/article/view/2797/1913) diakses 8 September 2016

Sa'adah, Aliyatus., Sugiyanto dan Sutarman. 2014. Pengembangan Instrumen Tes Benar-Salah untuk Menilai Kemampuan
Berpikir Tingkat Tinggi pada Materi Dinamika Rotasi dan Keseimbangan Benda Tegar. Artikel. (online) (http://jurnal.online.um.ac.id/data/artikel/a rtikel662F729E1D404633A7770C86049 A5069.pdf) diakses 9 Desember 2016

Silver \& Hmelo, Cindy E. 2004. Problem-Based Learning: What and How Do Students Learn? Educational Psychology Review, Vol. 16, No. 3, September 2004. (online) (http://kanagawa.lti.cs.cmu.edu/olcts09/sit es/default/files/HmeloSilver_2004.pdf) diakses pada 11 Maret 2017

Sofiyah, S., Susanto, \& Setiawani, S. 2015. Pengembangan Paket Tes Kemampuan Berpikir Tingkat Tinggi Matematika Berdasarkan Revisi Taksonomi Bloom Pada Siswa Kelas V SD. Artikel Ilmiah Mahasiswa, 2016, I (1): 1-7.(online), (http://repository.unej.ac.id/bitstream/han dle/123456789/64108/SITI\%20SOFIYA H.pdf?sequence=1), diakses 8 September 2016

Weiss, R.E. 2003. Designing problems to promote higher-order thinking. New directions for teaching and learning, 2003(95), 25-31. (online), (http: //utmlead.utm.my/wp-content/uploads /2014/08/Designing-Problems-toPromote-Higher-Order-Thinking.pdf) diakses 22 Mei 2017 